\title{
Student Quality Management in Strengthening Al-Islam and Muhammadiyah at SMA Muhammadiyah 1 Taman
}

\section{Manajemen Mutu Bidang Kesiswaan Dalam Penguatan Al-Islam dan Kemuhammadiyahan di SMA Muhammadiyah 1 Taman}

\author{
Aminatus Syaadah*, Akhtim Wahyuni \\ 1)Program Magister Manajemen Pendidikan Islam, Universitas Muhammadiyah Sidoarjo, Sidoarjo, Indonesia
}

OPEN ACCESS

ISSN 2723-3774 (online)

Edited by:

Ima Faizah

Reviewed by:

Khozin

*Correspondence:

Aminatus Syaadah

amysmamita@gmail.com

Received: 20 Desember 2019

Accepted: 5 Maret 2020

Published: 25 Agustus 2020

Citation:

Syaadah A and Wahyuni A (2020)

Student Quality Management in

Strengthening Al-Islam and

Muhammadiyah at SMA

Muhammadiyah 1 Taman .

Kournal of Islamic and

Muhammadiyah Studies. 1:2.

doi: 10.21070/jims.v1vi2i. 1066
This paper discusses the importance of implementing quality management in student's field in strengthening Al-Islam and Kemuhammadiyahan. The quality of education is one of the benchmarks of the success of an educational process in school. This process starts from the input (input), the process (teaching and learning activities), to the output (graduates). The quality of education can be interpreted as the ability of school to manage operationally the components related to school, so as to produce added value to these components according to standard norms or general standard. Student sector is one of the important component in the management of education quality. This research is a qualitative-descriptive research which is expected to be able to uncover various information with a careful and meaningful description-analysis. Sources of data in this study include the principal, student vice principal, Al-Islam teacher and Kemuhammadiyahan teacher. Data collection is done by interview, observation, and documentation. As for the data analysis techniques through the stages of data reduction, data presentation and data analysis. The results of the study include (a) quality management in the field of student implemented based on the values of Al-Islam and Kemuhammadiyahan. (b) Islamic and Kemuhammdiyahan values are the quality standards of the student field.

Keywords: Quality Management, Al-Islam and Kemuhammadiyahan

Tulisan ini membahas tentang betapa pentingnya implementasi manajemen mutu bidang kesiswaan dalam penguatan Al-Islam dan kemuhammadiyahan. Mutu pendidikan merupakan salah satu tolok ukur keberhasilan sebuah proses pendidikan di sekolah. Proses ini mulai dari input (masukan), proses (kegiatan belajar mengajar), hingga output (lulusan). Mutu pendidikan dapat diarti-kan sebagai kemampuan sekolah dalam mengelola secara operasional terhadap komponen-komponen yang berkaitan dengan sekolah, sehingga menghasilkan nilai tambah terhadap komponen tersebut menurut norma atau standar baku. Bidang kesiswaan merupakan salah satu komponen penting dalam penyelenggaraan manajemen mutu pendidikan.Penelitian ini termasuk jenis penelitian 
kualitatif-deskriptif yang diharapkan mampu mengungkap berbagai informasi dengan deskripsi-analisis yang teliti dan penuh makna.Sumber data dalam penelitian ini meliputi kepala sekolah, waka kesiswaan, guru Al-Islam dan Kemuhammadiyahan. Pengumpulan data dilakukan dengan wawancara, observasi, dan dokumentasi.Adapaun tehnik analisa datanya melalui tahapan reduksi data, penyajian data dan analisa data. Hasil penelitian diantaranya adalah (a) manajemen mutu bidang kesiswaan diimplemnetasikan berdasarkan nilai-nilai Al-Islam dan Kemuhammadiyahan.(b) nilai-nilai Keislaman dan Kemuhammdiyahan menjadi standart mutu bidang kesiswaan.

Keywords: Quality Management, Al-Islam and Kemuhammadiyahan

\section{PENDAHULUAN}

Keberhasilan dalam penyelenggaraan sebuah lembaga pendidikan (sekolah) akan sangat bergantung kepada manajemen komponen-komponen pendukung kegiatan seperti kurikulum, kesiswaan, sarana-prasarana, hubungan masyarakat maupun pembiayaan. Komponenkomponen tersebut merupakan satu kesatuan yang termasnifestasi dalam satu paket kegitan dalam upaya pencapaian tujuan lembaga pendidikan (sekolah). Dengan kata lain bahwa semua komponen memiliki status dan peran yang sama dalam mencapai sutu tujuan pendidikan. Eksistensi komponen bidang kesiswaan menjadi sangat urgen karena segala aktifitas pembelajaran dan pendidikan di sekolah tidak dapat dipisahkan dari keberadaan peserta didik (siswa). Peserta didik merupakan subyek sekaligus objek dalam proses transformasi ilmu pengetahuan dan ketrampilan bahkan nilai yang diperlukan. Oleh karena itu keberadaan peserta didik merupakan salah satu penentu dari kebermutuan suatu lembaga pendidikan (sekolah). Sehingga implementasi manajemen mutu bidang kesiswaan menjadi indentik dengan mewujudkan mutu pendidikan secara umum. Dengan demikian maka peserta didik dapat berkembang secara maksimal baik potensi fisik, kecerdasan intelektual, sosial, emosional bahkan psikologis (mental).

Diskursus tentang kesuksesan peserta didik tidak dapat dilepaskan dari bagaimana proses pendidikan itu diselenggarakan, kebutuhan peserta didik dalam mengembangkan diri dan potensinya sangat beragam (hiterogen), ada yang bersifat akademik dan ada juga yang bersifat non akademis, bahkan ada yang menginginkan kesuksesan dalam hal kesholihan sosial. Proses interpretasi potensi dan keinginan peserta didik ini seringkali menimbulkan ketimpangan, ketidak sesuaian antara keinginan, minat, bakat dan ketentuan lainnya sehingga menyebabkan munculnya suatu persoalan yang membutuhkan layanan yang tepat dan bijak. Manajemen bidang kesiswaan berupaya mengisi kebutuhan akan layanan yang baik dan bijak dalam segala persoalan kesiswaan yang muncul dan berkembang dalam kehidupan sekolah.

\section{METODE}

Penelitian ini merupakan penelitian lapangan (field research) karena dilaksanakan secara real dan berdasarkan fakta yang ada di lapangan. Jenis penelitian ini adalah penelitian deskriptifkualitatif. Dengan penelitian ini akan membantu mencermati dan mendeskripsikan datadata sesuai dengan tujuan penelitian ini. Informan dalam penelitian ini adalah penyelenggara/pengelola, guru dan siswa SMA Muhammadiyah 1 Taman yang terdaftar dan aktif pada tahun pelajaran 2019 / 2020. Penelitian ini digunakan dengan maksud adalah untuk menemukan kenyataan-kenyataan ganda yang terdapat dalam data, membuat hubungan peneliti dengan responden menjadi lebih eksplisit, menguraikan latar secara penuh dan dapat membuat keputusan-keputusan tentang dapat tidaknya kepada suatu latar lainnya, dapat menemukan pengaruh bersama yang mempertajam hubungan-hubungan, dan memperhitungkan nilai-nilai secara eksplisit sebagai bagian dari analitik.

Pengumpulan data dilakukan dengan observasi, wawancara dan dokumentasi yang seterusnya dianalisis dengan cara deskriptif analisis dengan menggunakan metode induktif. Observasi dilakakukan sejak pra-penelitian dan selama proses penelitian berlangsung yang dibantu den- 
gan fieldnote dan observation checklist untuk mengetahui kondisi lingkungan dan kegiatan yang dilakukan dalam mengungkap peran manajemen mutu kesiswaan dalam meningkatkan alIslam dan kemuhammadiyahan (AIK) Proses wawancara dilaksanakan dengan cara tatap muka secara langsung antara peneliti dengan informan. Dokumentasi dilaksanakan untuk memperoleh data kebijakan berupa renstra, kurikulum, syllabus, dokumen mutu maupun Rencana Program Sekolah dan juga data lain berupa literature dan catatan yang mendukung penelitian ini. Adapun alasan penggunaan pendekatan induktif dalam analisis data adalah sebagaimana yang dijabarkan oleh Moleong and (2007)

\section{HASIL DAN PEMBAHASAN}

\section{Perspektif tentang Manajemen Mutu}

Istilah manajemen berasal dari kata management (bahasa inggris), turunan dari kata "to manage" artinya mengurusi P. and Hasibuan (2008). Pengaturan dilakukan melalui proses dan diatur berdasarkan urutan dari fungsi-fungsi manajemen untuk mewujudkan tujuan umum pendidikan Mulyasa (2007) Manajemen sering diartikan sebagai ilmu, kiat dan profesi. Sebagai ilmu pengetahuan, manajemen juga bersifat universal, dan mempergunakan kerangka ilmu pengetahuan yang sistematis dan mencakup kaidah-kaidah, prinsip-prinsip, serta konsepkonsep yang cenderung benar dalam semua situasi manajerial[[iii]] Manajemen juga dapat di definisikan sebagai upaya perencanaan, pengkoordinasian, pengorganisasian dan pengontrolan sumber daya untuk mencapai sasaran secara efektif dan efisien. Sulistyorini (2009)

Menurut Nawawi manajemen merupakan proses perencanaan, pengorganisasian, penggerakan, dan pengontrolan terhadap sumber daya manusia (SDM) dan sumber daya yang lain guna mencapai tujuan secara efektif dan efisien. 921 (1996)

Secara ilmiah dapat di jelaskan bahwa manajemen itu merupakan tercapainya suatu tujuan secara efektif dan efisien. Pengelolaah manajemen mutu di sekolah akan saling berkaitan antara guru, siswa, kepala sekolah, karyawan dan masyarakat yang dapat mewujudkan/meningkatkan mutu sekolah. Dalam mewujudkan mutu pendidikan dalam bentuk pelayanan untuk memuaskan peserta didik dan masyarakat (wali siswa) merupakan pekerjaan yang membutuhkan proses serta konsentrasi yang kontinu (berkelanjutan) karena sebuah lembaga pendidikan dikatanya sebagai lembaga yang bermutu adalah ketika dia mampu memberikan pelayanan maksimal bahkan melebihi perspektif dan harapan para stakeholder sekolah, seperti pendidikan dan tenaga kependidikan, atau pihak-pihak lain yang terkait, seperti wali siswa, penyandang dana, pemerintah atau dunia kerja / usaha sebagai pengguna lulusan pendidikan. Oleh karena itu untuk memberikan jaminan mutu terhadap customer maka lembaga pendidikan harus melakukan perubahan dan pengembangan yang berorientasi mutu. Sehingga mutu pendidikan harus dikelola dengan baik, tertib serta berkelanjutan agar mampu mewujudkan hasil dan tujuan yang telah dicapai.

\section{Fungsi-Fungsi Manajemen.}

Fungsi manajemen dapat diuraikan sebagaimana berikut:

Perencanaan (Planning)

Pada dasarnya perencanaan merupakan suatu aktivitas pengambilan keputusan tentang suatu sasaran atau target yang harus dicapai dalam jangka waktu tertentu. Oleh karena itu perencanaan dimaknai sebagai suatu keputusan masa depan tentang sesuatu yang harus di capai. Nawawi (2012) Sehingga perencanaan merupakan salah satu keyword bagi setiap kegiatan manajemen, Sagala (2008a) artinya bahwa tanpa perencanaan maka pelaksanaan suatu kegiatan akan mengalami kesulitan bahkan bisa saja gagal dalam mencapai tujuan yang diinginkan.

Pengorganisasian (Organizing)

Kegiatan membagi tugas dan tanggung jawab kepada orang atau pihak tertentu dalam satu kesatuan system yang telah disepakati. Oleh karena organizing dapat berfungsi untuk mengatur dan memperjelas tugas kinerja serta tanggung jawab masing - masing individu atau kelompok, pengorganisasian juga mengatur bagian-bagian kerja organisasi, sehingga dengan pengaturan tersebut dapat menjamin tujuan yang ditentukan. 
Pengorganisasian dapat pula dimaknai sebagai keseluruhan aktifitas manajemen dalam pengelompokan dan pembagian tugas, fungsi dan wewenang bahkan tanggung jawab masing masing untuk mewujudkan aktifitas-aktifitas yang berdaya guna dan berhasil guna. Purwanto (1984) Oleh karena itu dalam sebuah aktifitas pengorganisasian harus memperhatikan bakat minat yang dimiliki seseorang dan pengetahuan serta kepribadian.

Penggerakan (Actuating)

Pergerakan (Actuating) berarti merangsang anggota-anggota atau pihak - pihak tertentu agar melaksanakan tugas dan kewajibannya secara professional dan berkelanjutan. Manullang (2008) Pergerakan juga dapat dimaknai sebagai kemampuan pemimpin mempengaruhi orang atau keolompok untuk mencapai tujuan yang telah di tetapkan. Sagala (2008b) Penggerakan adalah usaha untuk menggerakkan atau mengarahkan tenaga kerja (man power) serta mendayagunakan fasilitas serta kompetensi yang dimiliki demi sebuah tujuan bersama. Oleh karena itu penggerakan sangat terkait dengan penggunaan berbagai sumber daya organisasi, seperti kemampuan memimpin, memberi motivasi, berkomunikasi, menciptakan iklim dan budaya organisasi yang kondusif menjadi kunci penggerakan.

Evaluasi (Controlling)

Pegawasan merupakan fungsi manajemen yang berguna untuk mengetahui seberapa jauh rencana yang telah ditetapkan sebelumnya dapat tercapai. Pengawasan itu dapat membantu pemimpin untuk mengukur efektivitas perencanaan, pengorganisasian, dan pelaksanaan yang terjadi di lapangan, serta dapat membantu pemimpin untuk mengambil tindakan atau keputusan yang akurat sebagai kebutuhan organisasi. Manullang (2008)

Menurut Mulyono pengawasan dilakukan melalui 3 tahap yaitu (a) menetapkan standar pelaksanaan (b) pelaksanaan kegiatan disesuaikan dengan standart. (c) memetakan kesenjangan antara pelaksanaan dengan standar serta rencana yang telah ditetapkan. Kemudian dilanjutkan dengan tindakan evaluasi serta upaya perbaikan. Sehingga evaluasi itu dilakukan melalui beberapa tahapan, yaitu:

Menjadikan standart mutu pelaksanaan sebagai dasar pijakan melakukan control

Menyesuaikan pelaksanaan dengan standart mutu yang ditetapkan

Mendeviasi bentuk kesenjangan yang terjadi.

Melakukan tindakan-tindakan RTL (Rencana Tindak Lanjut) sebagai upaya perbaikan sehingga tetap mampu mencapai tujuan sesuai rencana. Miles and Huberman (1994)

\section{Manajemen Kesiswaan}

Manajemen kesiswaan adalah usaha pengaturan peserta didik yang dimulai sejak pertama kali siswa masuk hingga mereka lulus sekolah Mulyono (2008) Manajemen kesiswaan dapat diartikan sebagai seluruh proses kegiatan yang direncanakan secara sengaja yang dilakukan secara terus menerus agar dapat mengikuti proses pendidikan secara efektif dan efisien yang dilakukan oleh Pembina siswa. Prihatin (2011)

Dari beberapa pengertian di atas dapat di simpulkan bahwa manajemen kesiswaan merupakan proses segala hal yang berkaitan dengan siswa mulai dari penerimaan, kegiatan, hingga keluarnya peserta didik dari suatu lembaga sekolah.

Tujuan manajemen kesiswaan adalah untuk mengatur berbagai kegiatan sekolah yang terkait dengan keberadaan siswa demi tercapainya tujuan pendidikan. Gunawan (1996) Oleh karena itu manajemen kesiswaan yang baik dan berdaya guna akan membantu meringankan tugas pendidikan dan tenaga kependidikan bahkan pengelola dan masyarakat dalam meningkatkan kualitas pendidikan disebuah sekolah sehingga mutu dan derajat sekolah harus terimplementasi dalam sistem sekolah. Mulyasa (2007) Kesimpulannya bahwa tujuan manajemen kesiswaan adalah mengelolah berbagi aktifitas siswa serta ajang pengembangan diri dan bakat serta kompetensinya.

Ruang lingkup manajemen kesiswaan dalam suatu lembaga pendidikan (sekolah) meliputi:

\section{Analisis tentang Al-Islam dan Kemuhammadiyahan}

Al-Islam dan Kemuhammadiyahan (AIK) adalah salah satu mata pelajaran yang merupakan kekhasan sekolah - sekolah Muhammadiyah pada umumnya yang diselenggarakan mulai tingkat dasar hingga perguruan tinggi. Harapannya adalah untuk menumbuhkan bahklan memperkuat karakter peserta didik melalui implementasi pembelajaran langsung. 921 (1994) Adanya mata pelajaran Al-Islam dan Kemuhammadiyahan juga dimaksudkan untuk 
TABLE 1 | RuangLingkup Manajemen Kesiswaan

\begin{tabular}{lll}
\hline No & Variabel inti & Variabel Ruang Lingkup \\
1 & Penerimaan Siswa Baru & \\
& & 1. Penetapan Persyaratan \\
& & 2. Pembentukan Panitia PPDB \\
& Maping Kemajuan Belajar Siswa (Penjurusan) & 3. Masa Forum Ta'aruf Siswa \\
& 1. Jurusan IPA \\
& 2. Jurusan IPS \\
& Pegarahan dan Pembinaan Disiplin Siswa & 1. Pembinaan Disiplin siswa \\
& 2. Kegiatan Organisasi kesiswaan (IPM /OSIS) \\
& 3. Kegiatan kurikuler dan ekstra-kurikuler \\
\end{tabular}

mengantarkan peserta didik agar memiliki keyakinan yang benar, akhlaq yang baik (mulia), cerdas, terampil dan siap mengabdi bagi kepentingan bangsa dan umat sehingga kehidupan baldatun toyyibatu warabbun ghafur dapat terealisasi dalam kehidupan umat.

Al-Islam dan Kemuhammadiyahan (AIK) ini menjadi ciri khas dari lulusan sekolah sekolah Muhammadiyah yang nantinya akan mengabdi dalam kehidupan masyarakat dengan mencerminkan nilai-nilai Al-Islam dan kemuhammadiyahan dalam kehidupan sehari - harinya. Artinya bahwa Bekal keislaman yang diharapkan dimiliki oleh lulusan sekolah Muhammadiyah melalui pembelajaran Al-Islam Kemuhammadiyahan (AIK) adalah pelajar (manusia) yang memiliki bekal keIslaman yang kuat, memahami arti perjuangan Muhammadiyah, toleransi, mengetahui asal-usul atau sejarah pendirian muhammadiyah serta seluk beluk organisasi ini. 921 (2010)

Manajamen Mutu Kesiswaan dalam Penguatan Al-Islam dan Kemuhammadiyahan. (Analisis Hasil Penelitian)

Berdasakan hasil wawancara dan interview serta pemeriksaan dokumen - dokumen penting lainnya, maka dapat disampaikan hasil penelitian bahwa para peserta didik maupun warga sekolah yang lainnya dengan tekun dan tanpa paksaan melaksanakan nilai-nilai Al-Islam dan Kemuhammadiyahan, baik yang berdimensi aqidah, ibadah, maupun muamalah (akhlak).

Ada beberapa nilai yang terkandung dalam Al-Islam dan Kemuhammadiyahan, yaitu:

Nilai Aqidah

Pendidikan aqidah merupakan hal pertama dan utama untuk ditanamkan dan diperkuat dalam setiap proses pembelajaran, sebagai bentuk tanggung jawab kepada sang Pencipta. Dalam konsep Islam iman adalah meyakini dalam hati, diucapkan dengan lisan dan dibuktikan dalam bentuk perbuatan. 921 (2010) Aqidah dalam kehidupan sehari-hari dapat terimplementasikan dalam prilaku masing - masing individu maupun dan sosial masyarakat. Sehingga beriman adalah integrasi olah hati, lisan dan perbuatan sehingga Aqidah dapat dimaknai sebagai tindakan bekerja untuk tegaknya aqidah Islam yang murni bersih dari gejalagejala kemusyrikan, bid'ah dan khurafat, tanpa mengabaikan prinsip toleransi menurut ajaran Islam. Hendropuspito (2006)

Inti ajarannya tauhid adalah Pertama, pembebasan dari segala bentuk kemusyrikan pada Allah SWT. Kedua, hidup adalah beramal sesuai petunjuknya. Ketiga, Allah menjadi tujuan akhir segala aktivitas kehidupannya[[iii]]

\section{Nilai Ibadah}

Buah dari pendidikan aqidah adalah kuatnya ibadah. Karena setiap orang yang mempercayai dan mengimani Allah pasti akan memiliki keinginan untuk melaksanakan ibadah (ritual formal) yang direalisasikan secara ikhlas dan khusyuk. Hendropuspito (2006) Tetapi ibadah dalam perspektif Islam tidak bertujuan sebagai ritual penyembahan sebagaimana konsep sesembahan dalam agama lain. Sekalipun pengertian asal ibadah ibu adalah mengabdi atau menyembah. Dalam pandangan Islam Ibadah lebih sebagai sikap tunduk dan patuh terhadap ajaran yang ditentukan. Sebab syariat atau ajaran itu akan membawa pelakunya menuju kesuksesan. Sehingga dengan pengertian ini, ibadah bukan bentuk pengerdilan manusia justru sebagai pemebebasan manusia dari tirani kemusyrikan

\section{Nilai Akhlak}

Dimensi aqidah dan ibadah akan menghasilkan manusia yang berakhlaq baik. Akhlak sebe- 
narnya suatu bentuk manifestasi dari aqidah dan ibadah yang baik. Oleh karena itu aqidah, ibadah dan akhlaq memiliki keterkaitan yang sangat erat, satu sama lainnya saling memberikan pengaruh. Aqidah ibaratnya pondasi, kemudian ibadah adalah prosesnya dan akhlaq adalah buahnya. Berdasarkan pemahaman tersebut dapat disimpulkan bahwa aqidah dan ibadah yang baik akan menyebabkan manusia yang melakukannya juga baik. Begitu juga sebaliknya.

\section{Proses Internalisasi Nilai Al-Islam dan Kemuhammadiyahan}

Dalam pandangan Islam suatu proses pendidikan tidak hanya dimaknai sebagai uapaya mengetahui dan mengenalkan melainkan lebih dari itu yaitu memahami, serta mampu menjadikannya menyatu dengan sikap dan perbuatannya. Meminjam istilahnya Naquib Al-Attas, bahwa dalam pendidikan Islam melekat tiga element dasar yaitu: Process, content, and receipent (proses-isi-penerima). Proses yang dimaksud adalah penanaman isi sesuatu kepada murid. Karena itu, internalisasi juga dikenal dengan personalisasi. Sebuah upaya memasukkan pengetahuan atau (knowing) dan keterampilan melaksanakan (doing) itu ke dalam pribadi seseorang. Sehingga pendidikan Islam belum bisa dikatakan sukses jika belum mampu memasukkan pengetahuan berupa nilai - nilai kearifan yang terintegrasi dalam prilaku hidupnya sehari hari.

Implementasi nilai - nilai keislaman dan kemuhammadiyah tersebut dapat dilakukan dengan model:

\section{Uswah (Keteladanan)}

Keteladanan merupakan sesuatu yang penting dalam pendidikan oleh karena itu seorang guru atau pelaku pendidikan lainnya harus mampu memberikan contoh / teladan bagi peserta didiknya. bahwa pendidikan adalah meneladankan kepribadian muslim dalam segala aspeknya baik pelaksanaan ibadah maupun mu’amalah (sosial) sikap keteladan ini menjadi sikap yang melekat dan terpancar dalam setiap diri para peserta didiknya. Hendropuspito (2006) Dalam Al-Quran, keteladanan merupakan suatu metode yang dicontohkan oleh Rasulullah Muhammad SAW.

Artinya: Sesungguhnya telah ada pada (diri) Rasulullah itu suri teladan yang baik bagimu (yaitu) bagi orang yang mengharap (rahmat) Allah dan (kedatangan) hari kiamat dan dia banyak menyebut Allah. Shihab (1997)

\section{Pembiasaan}

Pembiasaan sebenarnya lebih sebagai kegiatan yang dilakukan secara berulamg - ulang dan terus menerus. Dalam konteks ini pembiasaan prilaku aqidah, ibadah dan akhlaq merupakan substansi dari proses pendidikan. Menurut Tafsir, akhlak yang baik dapat dicapai dengan keberagamaan yang baik. Sedangkan keberagamaan yang baik dicapai dengan antara lain dengan pembiasaan. 921 (1985) F. Muin menjelaskan bahwa perbuatan-perbuatan yang baik sebagai cerminan akhlaq dan dilakjukan secara berulang-ulang tanpa melalui proses pemikiran terlebih dahulu.[[ii]] Sehingga melekat dan menjadi karakteristik yang tidak terpisahkan dengan pribadinya.

Oleh karena itu proses pendidikan dituntut untuk terus membiasakan nilai - nilai AIK dalam kehidupan peserta didik bahkan menjadi budaya sekolah (school culture) yang tercermin dalam prilaku dan sikap peserta didik.

Dalam perspektif Zahra bahwa proses internalisasi dilakukan dengan cara pembiasaan dan peneladanan. Pembiasaan yang dimaksud adalah pembiasaan yang diawali dengan penanaman dan pemahaman peserta didik. oleh karena itu pembiaaan itu harus (1) dimulai sejak dini (2) dilakukan secara terus menerus (3) dilakukan secara teratur (4) pembiasaan yang disertai kata hati dan kesadaran diri (5) di awasi secara ketat, konsisten dan tegas. Handitya (2017)

\section{Jamuan (pengkondisian)}

Jamuan memiliki arti pertemuan dalam sebuah acara resepsi. Quraish Shihab mengutip perkataan Rasulullah, bahwa "Ayat-ayat adalah jamuan Allah". Baginya, Allah mengundang manusia untuk menelaah ayat-ayatNya. Menghadiri undangan-Nya berarti menikmati santapannya. Kenikmatan makanan dalam suatu jamuan akan semakin terasa dengan kehadiran teman-teman yang berbudi. Tafsir (2010a)

Menurut Naquib Al-Attas, Ada empat unsur dalam inviting to a banquet yang digambarkan Naquib di atas. Pertama, kondisi dan suasana yang ada di dalam pendidikan harus baik. Kedua, isi dari pendidikannya harus mengandung kebaikan. Ketiga, orang-orang di seke- 
lilingnya adalah orang-orang baik dan terhormat. Keempat, cara-caranya dilakukan dengan etika. Tafsir (2010b) Jika dilihat dalam

pendidikan, terutama dalam proses internalisasi pendidikan Agama Islam. Teknik jamuan adalah teknik yang seharusnya diimplementasikan dalam proses internalisasi nilai - nilai AIK pada diri peserta didik. Budaya salim, salam, senyum, sopan, santun adalah begian-bagian terkecil dari upaya menciptakan peserta didik yang kuataqidahnya, benar ibdahnya dan baik akhlaqnya.

Di sini peran mata penting pelajaran AIK karena didalmnya telah terkandung nilai - nilai yang dapat dikonversi dalam sikap dan prilaku keseharian. Kandungan nilai dalam AIK sejalan bersama dengan nilai keshalihan yang terintegrasi dalam manajemen mutu kesiswaan. Baik pendidikan akhlak, pendidikan aqidah, pendidikan ibadah, bahkan pendidikan tentang sejarah.

\section{Berkelanjutan (Istiqamah)}

Pendidikan adalah merupakan proses yang berlangsung seumur hidup (long life education) berlangsung dari masa ke masa (muda - tua). Oleh karena itu belajar itu harus dilakukan dengan continue dan seumur hidup sehingga nilai - nilai kemanusiaan akan tertanam kuat dan memancar sebagai kebiasaan yang membumi. Gunadi (2017)

a. Berdasarkan pada ulasan hasil penelitian di atas maka dapat digenaralisasikan sebuah kesimpulan bahwa internalisasi AIK berbasis mutu bidang kesiswaan dapat diamati pada beberapa sikap peserta didik, sebagai berikut:

b. Sikap Religius: terintegrasi dalam bentuk semangat melakukan ibadah berjama’ah, membaca Al-Qur'an dan sunnah - sunnah lainnya.

c. Sikap Moderat (keshalihan sosial) yang yang ditunjukkan dengan rasa kasih sayang, kesantunan, saling mendukung dan meperkuat, bersikap kritis terbuka dalam memandang perbedaan.

d. Sikap cerdas dan berilmu yang ditunjukkan dengan semangat literasi yang sangat tinggi, terlebih dijaman tehnologi imformasi yang perkembangannya semakin tidak terbendung.

e. Sikap Mandiri, sikap ini mampu mengantarkan peserta didik menjadi insan yang disiplin, mandiri dan bertanggung jawab akan diri dan lingkunnya.

f. Sikap bekerjasama dengan orang atau pihak lain, berupa solidaritas dan kepedulian sosialnya yang sangat tinggi.

TABLE 2 | Nilai - nilai Al-Islam dan Kemuhammadiyahanberbasis sekolah

\begin{tabular}{|c|c|c|}
\hline \multirow[t]{3}{*}{ No } & Nilai AlK & Keterangan \\
\hline & & Berdo'a sebelum memulai dan mengakhiri pelajara \\
\hline & & Sholat berjamaah di sekolah maupun di rumah \\
\hline \multirow[t]{4}{*}{1} & Nilai-nilai AIK (Aqidah \& Ibadah ) & $\begin{array}{l}\text { Membiasakan berdzikir dan bertadabbur akan } \\
\text { kekuasaan Allah SWT. }\end{array}$ \\
\hline & & $\begin{array}{l}\text { Membiasakan membaca al qur'an sebelum memu- } \\
\text { lai dan menutup pelajaran }\end{array}$ \\
\hline & & $\begin{array}{l}\text { Mewujudkan literasi sekolah melalui pembelajaran } \\
\text { BTQ }\end{array}$ \\
\hline & & Membiasakan mengucapkan dan menjawab salam \\
\hline \multirow[t]{3}{*}{2} & ilai-nilai AIK (Akhlaq dan Kesopanan) & $\begin{array}{l}\text { Membiasakan tradisi salim dengan bapak/ibu guru, } \\
\text { orang tua maupun teman sebaya yang sejenis } \\
\text { kelamin. }\end{array}$ \\
\hline & & $\begin{array}{l}\text { Membudayakan sikap jujur, disiplin, buang sampah } \\
\text { pada tempatnya, serta berpakaian sesuai syar'ih } \\
\text { Islam }\end{array}$ \\
\hline & & Kemandirian \\
\hline \multirow{3}{*}{3} & Nilai-nilai AIK (Keshalihan sosial) & Jujur dan tanggungjawab \\
\hline & 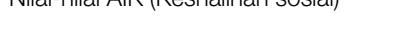 & Profesionalisme \\
\hline & & Jiwa nasionalisme \\
\hline
\end{tabular}

\section{PENUTUP}

Berdasarkan pada ulasan hasil penelitian di atas maka dapat digenaralisasikan sebuah kesimpulan bahwa internalisasi AIK berbasis mutu bidang kesiswaan dapat diamati pada beberapa 
sikap peserta didik, adalah:

Sikap Religius: terintegrasi dalam bentuk semangat melakukan ibadah berjama’ah, membaca Al-Quran dan sunnah - sunnah lainnya.

Sikap Moderat (keshalihan sosial) yang yang ditunjukkan dengan rasa kasih sayang, kesantunan, saling mendukung dan meperkuat, bersikap kritis terbuka dalam memandang perbedaan.

Sikap cerdas dan berilmu yang ditunjukkan dengan semangat literasi yang sangat tinggi, terlebih dijaman tehnologi imformasi yang perkembangannya semakin tidak terbendung.

Sikap Mandiri, sikap ini mampu mengantarkan peserta didik menjadi insan yang disiplin, mandiri dan bertanggung jawab akan diri dan lingkunnya.

Sikap bekerjasama dengan orang atau pihak lain, berupa solidaritas dan kepedulian sosialnya yang sangat tinggi.

\section{UCAPAN TERIMA KASIH}

Ucapan Terima kasih kepada Rektor Umsida, lembaga AIK, dan dosen pembimbing yang telah memberikan kesempatan berupa dukungan moril dan matriil bagi kami mahasiswa pasca sarjana magister manajemen pendidikan Islam Fakultas Agama Islam Umsida, dengan adanya acara seminar nasional AIK ke 2.

\section{REFERENCES}

(1985). Islam ditinjau dari berbagai aspeknya (Jakarta: Penerbit Universitas Indonesia), 33-33.

(1994). Dimensi-Dimensi Administrasi Pendidikan di Sekolah (Surabaya: Usaha Nasional), 103-103.

(1996). Al-Ushul Al-Idariyah Li Al-Tarbiyah (Dar Al-Syuruq: $\mathrm{Rad})$.

(2010). Persepsi mahasiswa terhadap mata kuliah al Islam dan kemuhammadiyahan (AIK): Internalisasi nilai-nilai AIK Bagi Mahasiswa. Progresiva : Jurnal Pemikiran dan Pendidikan Islam 4, 61-61.

and, L. J. M. (2007). Metode Penelitian Kualitatif (Bandung Remaja Rosda Karya).

Gunadi, R. A. A. (2017). , Membentuk karakter melalui Pendidikan Moral pada Anak Usia Dini di Sekolah Raudhatul Athfal (RA) Habibillah,.

Gunawan, A. (1996). Administrasi Sekolah; Administrasi Pendidikan Mikro (Jakarta: PT Rineka Cipta).

Handitya, B. (2017). Peran Pendidikan dalam Membangun Moral Bangsa di Era Disrupsi,. In Prosiding Seminar Nasional Jurusan Politik dan Kewarganegaraan, ed. and others.

Hendropuspito (2006). Sosiologi Agama (Yogyakarta: Kanisius), 114-114.

Manullang (2008). Dasar-dasar manajemen (YOgjakarta: Gadjah Mada Univrsity Press), 17-17.

Miles, M. B. and Huberman, A. M. (1994). Qualitative data analysis: An expanded sourcebook. Thousand Oaks (Thousand Oaks, CA: SAGE Publication Ltd).

Mulyasa, E. (2007). Manajemen Berbasis Sekolah (Bandung: PT Remaja Rosdakarya), 45-46.

Mulyono (2008). Administrasi Dan Organisasi Pendidikan (Jogjakarta: AR-Ruzz Media Groups).

Nawawi (2012). Manajemen strategik (Yogyakarta: Gadjah Mada University Press).
P., M. S. and Hasibuan (2008). Manajemen, Dasar, Pengertian dan Masalah. vol. 6 (Jakarta: Bumi Aksara), 1-1.

Prihatin, E. (2011). Manajemen Peserta Didik (Bandung:: Alfabeta), 4-4.

Purwanto, N. (1984). Administrasi Pendidikan (Jakarta: Mutiara).

Sagala, S. (2008a). Administrasi Pendidikan (Bandung: Alfabeta), 46-47.

Sagala, S. (2008b). Administrasi Pendidikan (Bandung:: Alfabeta), 52-52.

Shihab, Q. (1997). Wawasan Al-Qur”an (Bandung: Mizan), 9-9.

Sulistyorini (2009). Strategic Manajemen for Educational Manajemen : Manajemen Strategik Untuk Manajemen Pendidikan (Bandung: Alfabeta), 12-12.

Tafsir, A. (2010a). Filsafat Pendidikan Islam (Bandung: Rosda Karya), 22-22.

Tafsir, A. (2010b). Pendidikan Karakter Kontruksi Teoretik dan Praktik (Bandung: PT. REMAJA ROSDAKARYA), 223-224.

Conflict of Interest Statement: The authors declare that the research was conducted in the absence of any commercial or financial relationships that could be construed as a potential conflict of interest.

Copyright (c) 2020 Syaadah and Wahyuni. This is an openaccess article distributed under the terms of the Creative Commons Attribution License (CC BY). The use, distribution or reproduction in other forums is permitted, provided the original author(s) and the copyright owner(s) are credited and that the original publication in this journal is cited, in accordance with accepted academic practice. No use, distribution or reproduction is permitted which does not comply with these terms. 